\title{
18. BENTHIC FORAMINIFERS OF SITE 533, LEG 76 OF THE DEEP SEA DRILLING PROJECT- FAUNAL VARIATIONS DURING THE PLIOCENE AND PLEISTOCENE ON THE BLAKE OUTER RIDGE (WESTERN NORTH ATLANTIC) ${ }^{1}$
}

\author{
L. Blanc-Vernet, Laboratoire de Géologie Marine, Faculté des Sciences de Luminy, Case 901 , \\ 13288 Marseille Cedex 9, France
}

\begin{abstract}
Middle Pliocene to Recent sediments of Site 533, Leg 76, contain a benthic foraminiferal fauna characteristic of the bathyal zone. Few abyssal species are present. Reworked forms of the shelf and the upper slope are rare.

The Matuyama/Bruhnes boundary occurs above Sample 533-14,CC. Sample 533-1-2, 18-20 cm corresponds to the last glacial stage. Similar faunas-and probably analogous environmental conditions-are present in some earlier levels (Pleistocene and upper Pliocene). The Holocene fauna is characterized by a low specific diversity and the abundance of Globocassidulina moluccensis, which is not present before.
\end{abstract}

\section{INTRODUCTION, PROCEDURES}

Forty samples ranging in age from middle Pliocene to Recent were examined from Site 533 (see Fig. 1 for location). Three stratigraphic intervals were studied in more detail, the number of samples studied by core varying from one to three. In addition, eleven core catchers, located between the first and the second interval, were also examined in order to obtain an estimation of the Pleistocene faunal variation.

The list of the samples studied is given in Table 1. The Pliocene/Pleistocene boundary (FAD_first appearance datum-of Globorotalia truncatulinoides) is located between Sections 1 and 2 of Core 38. A more precise zonation established from planktonic species (M. Moullade, this volume) is indicated in Figure 2: the sediments studied belong to stratigraphical zones PL3 (test interval 3), PL5, PL6 and the base of N22 (test interval 2), and $\mathrm{N} 22 / 23$ (test interval 1). The correspondence between Pleistocene samples and Ericson's climatic zones is also indicated in Figure 2.

The number of foraminifers present in each sample varies considerably and is generally low. As far as possible, I have used tests larger than $160 \mu \mathrm{m}$. In two samples, however, the sediment was sieved with a $200 \mu \mathrm{m}$ mesh and the finer fraction was lost. On the other hand, in some core catchers, the size fraction between 160 and 63 $\mu \mathrm{m}$ was retained. This residue included many tiny forms - mainly Bolivina - which did not appear in the coarser sediments.

For these reasons, the results obtained from the different samples are not exactly comparable. Thus in Figure 2 the frequencies indicated are only approximations. Similarly, when the number of specimens in a sample was too low, the species present were noted by "+" without any frequency estimation. This is the case for Hole 533A samples.

${ }^{1}$ Sheridan, R. E., Gradstein, F. M. et al., Init. Repts. DSDP, 76: Washington (U.S. Govt. Printing Office).
FAUNAL ANALYSIS

\section{Abundance}

The number of benthic foraminifers larger than 160 $\mu \mathrm{m}$ is very different from one sample to another, ranging from 3 to 203, as indicated in Figure 2.

The calculated number of specimens per gram of sediment ranges from two to ten in test interval 1; it is somewhat higher during early Pleistocene and late Pliocene, with a maximum of 22.8 in Sample 533-38-X, 17-19 cm; in all the other samples but one, it is less than 2.6 (Section 533-38-X is located between 533-37,CC and 53338-1, 149.5-154 m sub-bottom.)

There is no trace of test solution, as might be expected from the paleo-water depth.

\section{Specific Composition}

About 80 species were encountered; 73 of them were determined at the specific level and listed in the Appendix with taxonomic references and stratigraphical and ecological indications. The different species of some genera (Bolivina, Fissurina, Lagena, Lenticulina, and Ooli$n a$ ), occurring sporadically and with few specimens, were not separated. The number of species per sample varies from 2 to 42 .

\section{Species Distribution}

Figure 2 shows the occurrence of the main species with, when possible, an estimation of their frequencies. They are listed in the order of their vertical distribution, with the exception of the presumed reworked forms.

Some species occurring sporadically are not indicated in the Figure, such as Ammoscalaria tenuimargo (53337-2, 25-27 cm), Cornuspira involvens (533-21,CC), Dentalina inornata bradyensis $(533 \mathrm{~A}-29, \mathrm{CC}), D$. subemaciata (533-38-X, 17-19 cm), Epistominella exigua (533$38-2,15-17 \mathrm{~cm})$, Globocassidulina subglobosa (533A29-3, 40-42 cm), G. crassa (533-37-1, 47-49 cm), Laticarinina pauperata $(533-40, \mathrm{CC})$, Nuttalites rugosus-convexus (533-38-X, 17-19 cm), Osangularia cultur (533-37- 


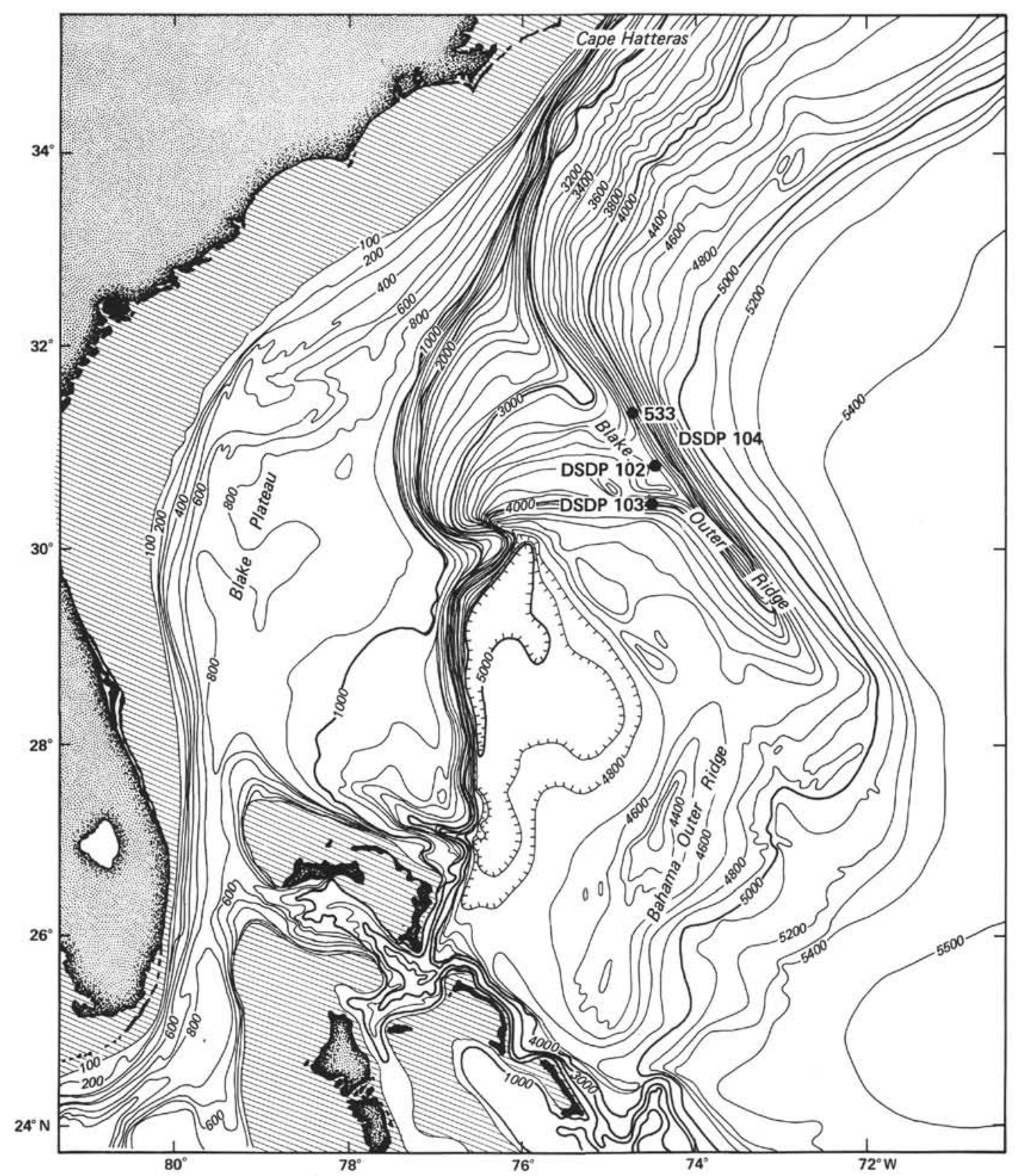

Figure 1. Location of Site 533.

1, 47-49 cm), Stilostomella abyssorum (533-39-3, 33-35 $\mathrm{cm})$, Stilostomella bradyi $(533-6, \mathrm{CC})$.

The possible interpretations of the species distribution are discussed later. From bottom to top of the sequence, we can note the following facts:

Some species are limited to the Pliocene: Dentalina intorta, Nodosaria ovicula, Pseudonodosaria laevigata, and Dorothia sp.

Several others occur in the Pliocene and in a part of the Pleistocene: different species of Lenticulina, and $\mathrm{El}$ lipsopolymorphina brevis, Ellipsoidina ellipsoides, Orthomorphina fistuca, Stilostomella ex gr. lepidula, Plectofrondicularia advena.
The family Miliolidae is present throughout the section, but the genus Pyrgo is frequent, especially during the Pleistocene.

Many species show a large stratigraphic distribution. They are generally abundant, and some of them become dominant in certain samples, forming 20 to $50 \%$ of the assemblage, such as: Oridorsalis umbonatus, Cibicides wuellestorfi, the species of the genus Melonis, Uvigerina, Globobulimina, and Pullenia.

Few species are restricted to the Pleistocene: Cassidulina carinata, Chilostomella oolina, Francesita advena, Martinotiella communis, Siphotextularia catenata, Stainforthia complanata, Valvulineria laevigata. 
Table 1. List of samples studied.

\begin{tabular}{|c|c|}
\hline $\begin{array}{c}\text { Sample } \\
\text { (interval in } \mathrm{cm} \text { ) }\end{array}$ & Age \\
\hline \multicolumn{2}{|l|}{ Test interval 1} \\
\hline $\begin{array}{l}533-1-1,2.5-3.5 \\
533-1-1,18-20 \\
533-2-2,25-27\end{array}$ & $\begin{array}{l}\text { Recent and } \\
\text { uppermost } \\
\text { Quaternary }\end{array}$ \\
\hline \multicolumn{2}{|l|}{ Intermediate sampling } \\
\hline $\begin{array}{l}533-6, \mathrm{CC} \\
533-7, \mathrm{CC} \\
533-9, \mathrm{CC} \\
533-14, \mathrm{CC} \\
533-20, \mathrm{CC} \\
533-21, \mathrm{CC} \\
533-23, \mathrm{CC} \\
533-25, \mathrm{CC} \\
533-26, \mathrm{CC} \\
533-33, \mathrm{CC} \\
533-36, \mathrm{CC} \\
\end{array}$ & Quaternary \\
\hline \multicolumn{2}{|l|}{ Test interval 2} \\
\hline $\begin{array}{l}533-37-1,47-49 \\
533-37-2,25-27 \\
533-38-X, 17-19 \\
533-38-1,75-77\end{array}$ & $\begin{array}{c}\text { lower } \\
\text { Quaternary }\end{array}$ \\
\hline $\begin{array}{l}533-38-2,15-17 \\
533-38-2,106-108 \\
533-38-3,25-27 \\
533-39-1,48-50 \\
533-39-3,33-35 \\
533-40-1,38-40 \\
533-40-2,36-38 \\
533-40, C C \\
533-41-1,47-49 \\
533-41-2,42-44 \\
533-41-3,27-29\end{array}$ & $\begin{array}{c}\text { upper } \\
\text { Pliocene }\end{array}$ \\
\hline \multicolumn{2}{|l|}{ Test interval 3} \\
\hline $\begin{array}{l}533 \mathrm{~A}-26, \mathrm{CC} \\
533 \mathrm{~A}-27-2,88-90 \\
533 \mathrm{~A}-27-4,120-122 \\
533 \mathrm{~A}-27-6,100-102 \\
533 \mathrm{~A}-27, \mathrm{CC} \\
533 \mathrm{~A}-28-2,34-36 \\
533 \mathrm{~A}-28, \mathrm{CC} \\
533 \mathrm{~A}-29-2,88-90 \\
533 \mathrm{~A}-29-3,40-42 \\
533 \mathrm{~A}-29-4,48-50 \\
533 \mathrm{~A}-29, \mathrm{CC}\end{array}$ & $\begin{array}{l}\text { middle } \\
\text { Pliocene }\end{array}$ \\
\hline
\end{tabular}

Three species occur only in the uppermost stratigraphic level (533-1-1, 2.5-3.5 cm): Globocassidulina moluccensis, Karreriella apicularis, Rhabdammina linearis.

\section{DISCUSSION}

\section{Vertical Distribution and Stratigraphic Implications}

The majority of the species encountered in the two holes have a large time range and cannot be used for stratigraphic indexing. In most cases, especially when the species are rare, their absence may be due to the small size of the samples. It is also difficult to know whether the occurrences of the observed species depend on stratigraphic, ecologic, or other features.
An important fact that must be emphasized is the disappearance in the late Pleistocene of a group of speciesEllipsoidina ellipsoides, Orthomorphina fistuca, Ellipsopolymorphina brevis, Plectofrondicularia advena, Stilostomella ex gr. lepidula. The first of these forms is described from the Miocene, but there are few indications about its level of extinction. The others are known to be extinct at the beginning of the Brunhes epoch (Lutze, 1979). In Hole 533, these forms disappear between Samples 533-37-2, 25-27 cm and 533-14,CC. Three species only occur in the upper levels (test interval 1). This occurrence is difficult to explain: all three are known to be present in recent sediments from different seas in bathyal or abyssal zones. Their restricted occurrence is probably not a stratigraphic fact but may be a response to local ecological conditions.

\section{Bathymetric Interpretation of the Fauna}

Several recent publications deal with the bathymetric zonation of benthic foraminifers and give a review of older works, for example, for the Atlantic Ocean, Phleger et al. (1953), Pujos-Lamy (1973), Berggren and Haq (1976), Pflum and Frerichs (1976), Lutze (1978), Schnitker (1979), and so on. Results from the Pacific Ocean (Ingle, 1980; Ingle et al., 1980; Boltovskoy, 1981) and the Indian Ocean (Corliss, 1979) were also compiled. Although there are some differences in the detail of the species distribution in different areas, most of the forms found in Holes 533 and 533A have a similar depth range. The majority of them have their upper depth limit below $1000 \mathrm{~m}$ (middle bathyal), and most become more abundant in lower bathyal zones, even in abyssal zones (cf., Appendix), for example, Cibicides kullenbergi, Eggerel la bradyi, Eponidestumidulus, Epistominella exigua, Francesita advena, Gyroidina soldanii, Karreriella apicularis, Melonis pompilioides, Oridorsalis umbonatus, Quinqueloculina venusta, Uvigerina canariense, U. senticosa.

Thus the assemblage composition seems to be in agreement with the present water depth of the drilling site.

\section{The Displaced Faunas}

In the fraction coarser than $200 \mu \mathrm{m}$, only two species can be considered as displaced. They are Cibicides lobatulus $(533-33, \mathrm{CC})$ and Textularia sp. $(533-36, \mathrm{CC})$.

In the residue between 200 and $160 \mu \mathrm{m}$, the reworked species are a little more abundant, but the number of such specimens in each sample never exceeds two or three. The concerned forms are Ammonia beccarii, Astrononion sp., Buliminella elegantissima, Elphidium sp., Neoconorbina sp., Nonionella $\mathrm{cf}$. stella, and Rosalina sp.

All these forms are living today in the neritic zone of the different seas; owing to their low frequencies, the displacements of sediments from the shelf seem to have been of little importance during the span of time investigated.

The fraction between 160 and $63 \mu \mathrm{m}$ contains many specimens of Bolivina belonging to three species: $B$. seminuda, B. ex gr. spathulata and Bolivina sp. The two former species have a large bathymetric distribution and 


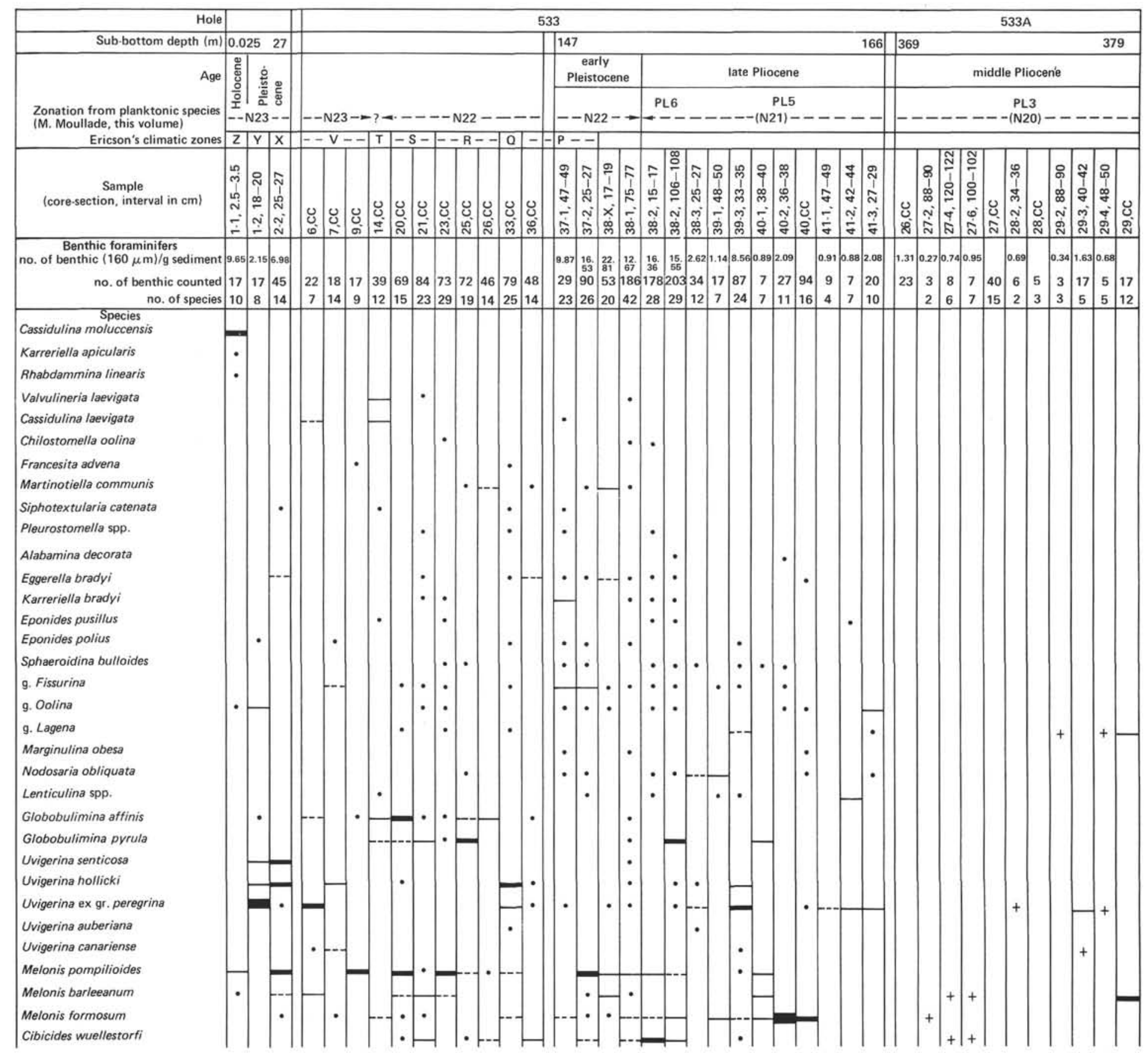




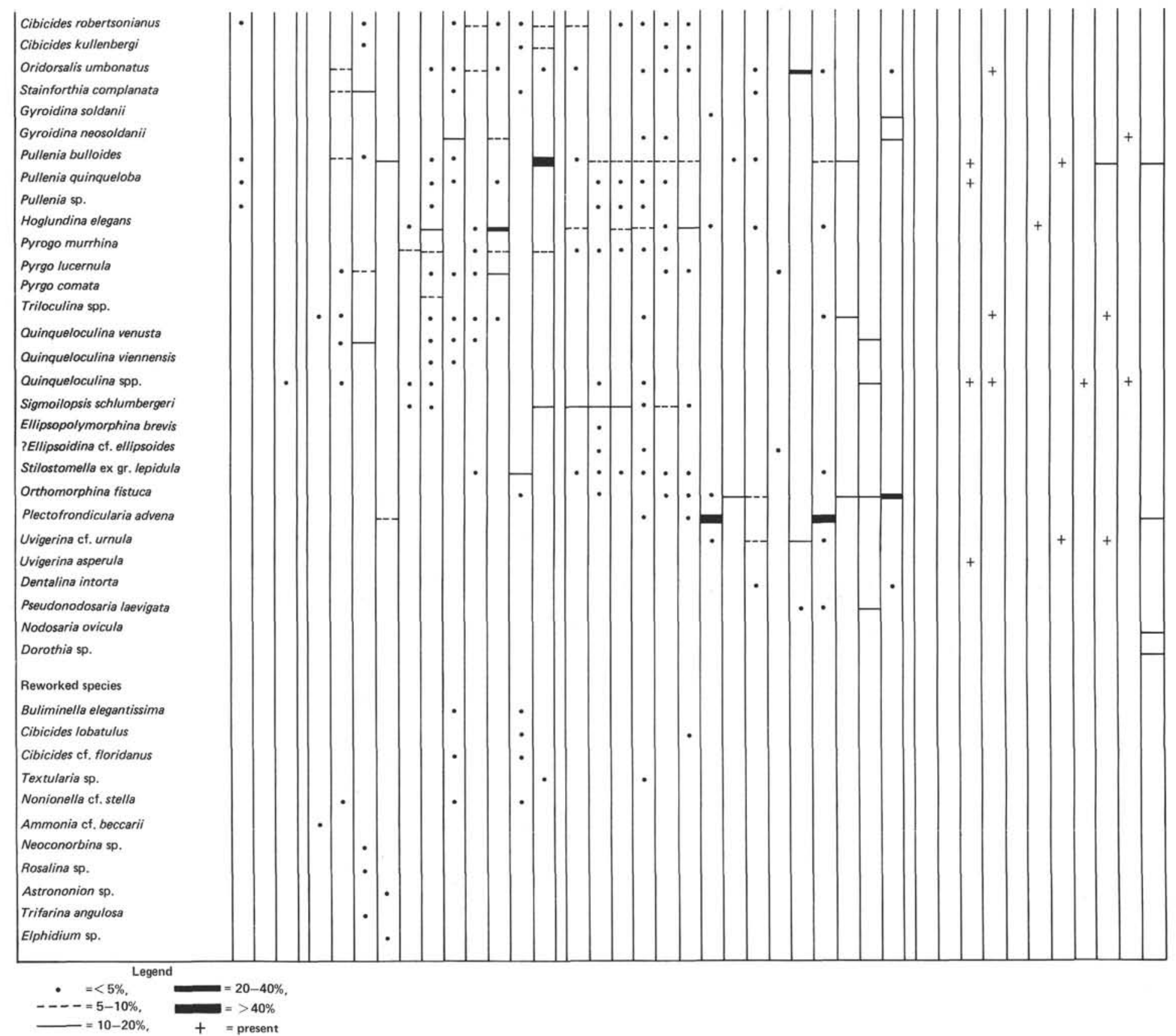

Figure 2. Distribution of the main benthic foraminifers in selected samples from Holes 533 and 533A. 
are sensitive to other ecological factors than depth, especially $\mathrm{O}^{2}$ contents (Boltovskoy and Wright, 1976). As they are present in all the sediments in which the finest fraction was preserved, we can assume that they are present throughout the core and they cannot yield any information on possible paleoecological changes.

\section{Other Factors}

In several levels, some taxa become dominant in the assemblage. As these species have generally the same bathymetric distribution, the causes of their abundance must be searched in the variation of other factors than depth. These forms are Globobulimina, Melonis, Pullenia, Uvigerina, and also Cibicides wuellestorfi and Oridorsalis umbonatus.

Within the bathyal and abyssal zones, several authors have emphasized the fact that these species are more or less associated with the properties of the different bottom-water masses, mainly temperature, salinity, oxygen, and carbonate contents.

Streeter (1973), Schnitker (1974), Lohmann (1978), and Gofas (1978) have shown that deep-sea benthic foraminifers may have responded to environmental changes by bathymetric or geographic migrations related to deepwater circulations. The case of Melonis pompilioides was especially studied on the California borderland (Blake and Douglas, 1980).

For the western North Atlantic, Schnitker (1980) presented a model of correlations between the displacement of bottom-water masses during the last $24,000 \mathrm{yr}$. and the abundance and distribution of some "index species." He stated that in recent time, as in interstadial periods, Epistominella exigua, a dominant fauna, accompanied by Cibicides wuellestorfi characterized the "North-Atlantic deep water" that occupied the northern part of the North Atlantic $\left(32^{\circ} \mathrm{N}\right.$ latitude), whereas an Osangularia umbonifera fauna, corresponding to the "Antarctic bottom water," occurred in the southern part of the North Atlantic. At the same time, Uvigerina peregrina was restricted to shallower areas, along the North American continental margin and on the Mid-Atlantic Ridge.

During glacial periods, the displacement southward of the polar front induced changes in the distribution and circulation of water masses, and the Uvigerina fauna invaded most of the North Atlantic, especially the area where Site 533 is located. Pullenia faunas seem to characterize oxygen-depleted waters in some limited intervals.

In the Bay of Biscay, Schnitker (1979) also found that Uvigerina peregrina (associated with Pyrgo murrhina) characterizes glacial stages, whereas $C$. wuellestorfi, Epistominella exigua, Oridorsalis umbonatus, Melonis pompilioides, M. barleeanus, Pullenia bulloides, P. quinqueloba, and so on become dominant in interglacial and postglacial times.

Globobulimina affinis and G. pyrula are listed neither in glacial nor in interglacial Atlantic faunas. Nevertheless, these species seem tolerant to low $\mathrm{O}^{2}$ contents (Mullineaux and Lohmann, 1981).

In order to compare the distribution of all these taxa in cores of Holes 533 and 533A, their variations are summarized graphically in Figure 3.
The following remarks can be proposed:

The species considered are very sparse in the third test interval (middle Pliocene), and no indication can be proposed.

Two of the "index species" of Schnitker (1980) are present: Uvigerina peregrina, whose extension in this area characterizes glacial stages, and Cibicides wuellestorf $i$, which is related to the presence of North Atlantic bottom waters during interstadial periods. Epistominella exigua, the main characteristic of this water mass, is present in one sample only $(533-37-2,25-27 \mathrm{~cm})$, but this scarcity may be due to the small size of this species. The absence of Osangularia umbonifera throughout the drilling may indicate that Antarctic bottom waters have never occupied this area during the periods investigated. This fact may also be due to the bathymetric position of the site.

Two sorts of assemblages can be distinguished: (1) An assemblage in which Uvigerina peregrina forms more than $10 \%$ of the fauna, often more than $30 \%$. This probably glacial assemblage is also characterized by low specific diversity (generally less than 12 species per sample). Such a fauna occurs in Samples 533-1-2, 18-20 cm; $533-6, \mathrm{CC}$; $533-38-3,25-27 \mathrm{~cm}$; 533-39-3, $33-35 \mathrm{~cm}$; 533-41-1, 47-49 cm, 533-41-2, 42-44 cm; and 533-41-3, $27-29 \mathrm{~cm}$. (2) In the other levels, the specific diversity is generally higher (up to 42 species per sample), and the dominant species are Melonis, Pullenia, Oridorsalis umbonatus, and Cibicides wuellestorfi. These levels may be interpreted as interglacial intervals. In some of these samples, the abundance of Globobulimina and perhaps also of Pyrgo murrhina may indicate a decrease in the oxygen contents. But there is no striking relationship between the presence of pyrite in some sediments and the abundance of these two species.

In the uppermost (postglacial) sample (533-1-1, 2.5$3.5 \mathrm{~cm}$ ), the fauna, and thus the environmental conditions, seems very peculiar and different from those of the preceding interglacial assemblages: some interglacial species are present but not abundant. The specific diversity is relatively low (10 species) and the only frequent species is Globocassidulina moluccensis, which was never present in lower levels. Burke (1981) thinks that this species could be influenced by carbonate deficiency, but in Core 533-1, it is impossible to verify this assumption. Two other species (Karreriella bradyi and Rhabdamina linearis) are also restricted to this upper level.

\section{CONCLUSIONS}

Holes 533 and 533A contain from bottom to top a lower bathyal fauna; in some levels some middle bathyal or abyssal species appear.

There are few species reworked from the shelf or from the upper slope.

Distribution of Uvigerina peregrina, on the one hand, and of Cibicides wuellestorfi, Melonis, Pullenia, Oridorsalis, and so on, on the other hand, are interpreted as reflecting movements of bottom-water masses during glacial and interglacial periods. There is a glacial fauna in Sample 533-1-2, 18-20 cm (last glacial stage). Other levels seem to indicate analogous environmental conditions during the Pleistocene and late Pliocene. 


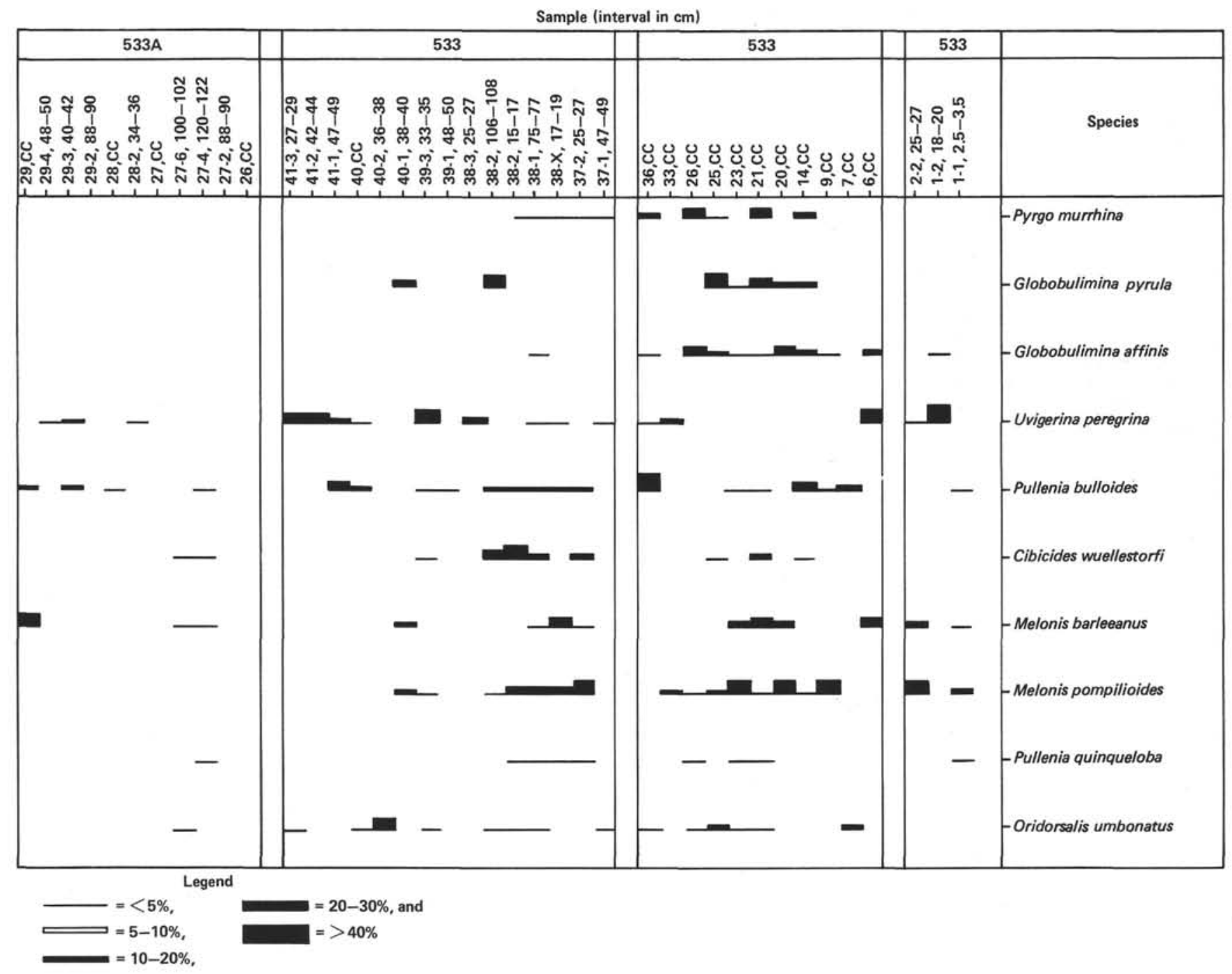

Figure 3. Distribution of dominant benthic foraminifers in selected samples from Holes 533 and 533A.

The recent assemblage is different in many ways from the previous interglacial faunas and may reflect peculiar conditions established during the Holocene.

\section{ACKNOWLEDGMENTS}

I am indebted to Drs. F. M. Gradstein and M. Moullade who have given me the opportunity to study this material and for their comments and suggestions. I also thank Drs. R. Anglada, E. Vincent, and H. Chamley who have reveiwed the manuscript.

\section{REFERENCES}

Berggren, W. A., and Haq, B. U., 1976. The Andalusian stage (late Miocene): biostratigraphy, biochronology, and paleoecology. $\mathrm{Pa}$ leogeogr. Paleoclimatol. Palaeoecol., 20:67-129.

Blake, G. H., and Douglas, R. G., 1980. Pleistocene occurrence of Melonis pompilioides in the California borderland and its implications for foraminiferal paleoecology. Cushman Found. Foraminiferal Res. Spec. Publ., 19:59-67.

Boltovskoy, E., 1981. Benthic Cenozoic foraminifera of DSDP Site 173 and comparison with the same faunas of other sites. Rev. Micropaleontol., 22(3/4):121-137.

Boltovskoy, E., and Wright, R., 1976. Recent Foraminifera: The Hague, Holland (Junk).

Burke, S. C., 1981. Recent benthic Foraminifera of the Ontong Java Plateau. J. Foraminiferal Res., 11(1):1-19.
Corliss, B. H., 1976. Influence of abyssal circulation on the distribution of benthic foraminifera in the southeast Indian Ocean. Trans. Am. Geophys. Union, 57:258.

1979. Taxonomy of recent deep sea benthic Foraminifera from the Southeast Indian Ocean. Micropaleontology, 25(1):1-19.

Gofas, S., 1978. Une approche du paleoenvironnement océanique: les foraminifères benthiques calcaires, traceurs de la circulation abyssale [thèse doct.]. Universite Bretagne Occidentale, Brest, France.

Ingle, J. C., Keller, J. R., and Kolpack, G., 1980. Benthic foraminiferal bio-facies, sediments and water masses of the southern Peru-Chile Trench area, Southern Pacific Ocean. Micropaleontology, 26(2):113-150.

Ingle, J. E., 1980. Cenozoic paleobathymetry and depositional history of selected sequences within the southern California continental borderland. Cushman Found. Foraminiferal Res. Spec. Publ., 19: 163-195.

Lohmann, G. P., 1978. Abyssal benthonic foraminifera as hydrographic indicators in the western South Atlantic Ocean. J. Foraminiferal Res., 8:6-34.

Lutze, G. F., 1979. Benthic Foraminifers at Site 397: faunal fluctuations and ranges in the Quaternary. In von Rad, U., Ryan, W. B. F., et al., Init. Repts. DSDP, 47, Pt. 1: Washington (U.S. Govt. Printing Office), 419-432.

, 1978. Neogene benthonic foraminifera from Site $369 \mathrm{Leg}$ 41, Deep sea drilling project. In Lancelot, Y., Seibold, E., et al., Init. Repts. DSDP, 41: Washington (U.S. Govt. Printing Office), 659-666. 
Mullineaux, L. S., and Lohmann, G. P., 1981. Late Quaternary stagnations and recirculation of the eastern Mediterranean: changes in the deep water recorded by fossil benthic Foraminifera. J. Foraminiferal Res., 11(1):20-39.

Pflum, C. E., and Frerichs, W. E., 1976. Gulf of Mexico deep water Foraminifera. Cushman Found. Foraminiferal Res. Spec. Publ., 14:7-125.

Phleger, F. B., Parker, F., and Peirson, J., 1953. Sediments cores from the North Atlantic Ocean. Repts. Swed. Deep-Sea Exped., 8: $1-12$.

Pujos-Lamy, A., 1973. Répartition bathymétrique des foraminiferes profonds du golfe de Gascogne: comparaison avec d'autres aires oceaniques. Rev. Esp. Micropaleontol., 5(2).

Schnitker, D., 1974. West Atlantic abyssal circulation during the past 120,000 ans. Nature, 248:385-387.

1979. Cenozoic deep water benthonic foraminifers, Bay of Biscay. In Montadert, L., Roberts, D. G., et al., Init. Repts. DSDP, 48: Washington (U.S. Govt. Printing Office), 377-414.

1980. Quaternary deep sea benthic foraminifers and bottom water masses. Ann. Rev. Earth. Planet. Sci., 8:343-370.

Streeter, S. S., 1973. Bottom water and benthonic foraminifera in the North Atlantic glacial-interglacial contrasts. Quat. Res., 3:131-141. 1976. Deep water benthic foraminiferal faunas in the Atlantic during the late Pleistocene. The significance of Uvigerinids peaks. Trans. Am. Geophys. Union, 57:258. (Abstract)

Date of Initial Receipt: August 26, 1982

\section{APPENDIX \\ Benthic Species from Holes 533 and 533A: Taxonomic and Paleoecological Notes}

Seventy-three species are listed alphabetically. For all species, reference is made to the original description (see Ellis and Messina's Catalogue of Foraminifera if the original work is not cited in the References). Additional references and remarks are added when necessary for more specific identification. The stratigraphic, bathymetric, or ecological distribution of the most important forms are given from the literature mentioned in the text.

Alabamina decorata (Phleger and Parker) = Pseudoparella $(?)$ decorata Phleger and Parker, 1951, p. 28, pl. 15, figs. 4-5. ico.

Distribution. Upper depth limit-about $900 \mathrm{~m}$ in the Gulf of Mex-

Site 533. Rare: upper Pliocene; Samples 533-38-2, 106-108 cm and $533-40-2,36-38 \mathrm{~cm}$.

Ammonia beccarii $($ Linné $)=$ Nautilus beccarii Linné, 1767, p. 710 .

Distribution. Neritic species.

Site 533. Probably reworked from the shelf. One specimen in Sample 533-6,CC.

Ammoscalaria tenuimargo $(\mathrm{Brady})=$ Haplophragmoides tenuimargo

Brady, 1882, Proc. Roy. Soc. Edin., 1884, p. 303, pl. 33, figs.

13-16.

Systematic remarks. There is some doubt about the taxonomic appartenance of the two fragments found in one sample only.

Distribution. Recorded in middle bathyal, lower bathyal, and abyssal zones.

Site 533. One sample: $533-37-2,25-27 \mathrm{~cm}$.

Bolivina ex gr. spathulata $($ Williamson $)=$ Textularia variabilis Williamson var. spathulata Williamson, 1858.

Remark. The specimen attributed by different workers to the " $\mathrm{BO}$ livina spathulata group" shows a great range of morphological variations.

Distribution. The different forms are reported from the outer shelf to bathyal environments.

Holes 533 and 533A. Frequent in the finest fraction $(160-163 \mu \mathrm{m})$. Bolivina seminuda Cushman, 1911, p. 34, fig. 55.

Distribution. It is generally reported deeper than the preceding species in the Gulf of Mexico, occurring in a lower bathyal zone.

Holes 533 and 533A. Frequent in the finest fraction $(160-163 \mu \mathrm{m})$. Buliminella elegantissima D'Orbigny, 1839.

Distribution. Neritic zone of the different oceans.

Site 533. Present in two samples (533-23,CC and 533-33,CC), probably reworked.
Cassidulina carinata (Silvestri) $=$ Cassidulina laevigata var. carinata Silvestri, 1896.

Distribution. Widely distributed in upper and middle bathyal zones. Site 533. Sparse during the Pleistocene.

Chilostomella oolina Schwager, 1878.

Distribution. Bathyal and abyssal zones of all the oceans.

Site 533. Sparse in the Pleistocene and upper Pliocene.

Cibicides kullenbergi Parker in Phleger, Parker, and Peirson, 1953, p. 49 , pl. 11 , figs. $7-8$.

Distribution. Described from the Atlantic ocean, where it is "widespread.... and a true deep sea form"; it occurs also in the Pacific and Indian oceans and in the Mediterranean. C. kullenbergi seems also to be a "warm" species in the Atlantic.

Site 533. Sparse in the Pleistocene, generally associated with $C$. robertsonianus and often with $C$. wuellestorfi.

Cibicides lobatulus (Walker and Jacob) $=$ Nautilus lobatulus Walker and Jacob, 1798

Distribution. Neritic species.

Site 533. In two samples, with one specimen only. Probably reworked.

Cibicides robertsonianus (Brady) $=$ Truncatulina robertsoniana Brady, 1881,1884 , p. 664 , pl. 95 , fig. 4 A-C.

Distribution. Bathyal species in the different seas.

Site 533. A little more frequent than $C$. kullenbergi.

Cibicides wuellestorfi $($ Schwager $)=$ Anomalina wuellestorfi Schwager, 1866.

Distribution. Frequent from the middle bathyal to abyssal zones; it is generally considered as an interglacial index in the North Atlantic. Site 533. Frequent and sometimes abundant in Pleistocene and Pliocene levels (see text).

Cornuspira involvens $=$ Operculina involvens Reuss, 1851 .

Site 533. Sample 533-21,CC.

Dentalina inornata (D'Orbigny) Bradyensis (Dervieux) $=$ Nodosaria inornata (D'Orbigny) bradyensis Dervieux, 1894.

Distribution. In the Gulf of Mexico, this species occurs in the bathyal and the upper part of the middle bathyal.

Hole 533A. In one sample only: 533-29, CC-middle Pliocene.

Dentalina intorta $($ Dervieux $)=$ Nodosaria intorta Dervieux, $1894=$ Nodosaria mucronata Brady, 1884, pl. 62, figs. 27-31.

Distribution. Gulf of Mexico: lower bathyal to abyssal zone.

Site 533. In upper Pliocene: Samples 533-39-3, 33-35 $\mathrm{cm}$ and 533 41-3, 27-29 cm.

Dentalina subemaciata Parr, 1950, p. 329, pl. 12, fig. 1.

Distribution. Widespread deep species.

Hole 533. Sample 533A-38-X, 17-19 cm.

Eggerella bradyi $($ Cushman $)=$ Verneuilina bradyi Cushman, 1911, $\mathrm{p}$. 54 , fig. 87.

Distribution. Bathyal and abyssal world-wide spread species.

Site 533. Frequent but never abundant in Pleistocene and upper

Pliocene.

Ellipsoidina ellipsoides Seguenza, 1859, Brady, 1868, p. 338, pl. 13, figs. 1-12.

Remarks. Two large specimens occur in Hole 533A (533A-35-2, 25-27 cm and 533A-38-1, 75-77 cm) and a broken one in Sample $533 \mathrm{~A}-40-1,38-40 \mathrm{~cm}$. They have an overlapping last chamber and seem identical with the figuration of Seguenza Miocene species.

The specimens also resemble Ellipsoglandulina antillea (Bermudez, 1939 , p. 247 , pl. 33 , figs. 1-2) but show no trace of the early chambers described by this author.

Site 533. This species is present in the upper Pliocene and in the lowermost Pleistocene (up to Sample 533-37-2, 25-27 cm).

Ellipsopolymorphina brevis $($ Schwager $)=$ Pleurostomella brevis brevis Schwager, 1866.

Distribution. The type is Pliocene. Brady (1884) records this species at $230 \mathrm{~m}$ depth in recent(?) sediments from Ki Island. But according to Lutze (1979), this species disappears at the beginning of the Brunhes Epoch.

Site 533. In Sample 533-35-2, 25-27 cm.

Epistominella exigua $($ Brady) $=$ Pulvinulina exigua Brady, 1884, p. 693 , pl. 103, figs. 13-14.

Distribution. There are some discrepancies between the interpretations proposed by various authors concerning the relations of this species with depth, temperature, and other factors. Schnitker (1980) considers this form an "index species" characterizing the Arctic bottom 
water and the lower North Atlantic deep water, which occupied the western part of the North Atlantic Basin during interglacial and postglacial times.

Site 533. E. exigua is rare, probably because this species is too small for the mesh sieve used $(160 \mu \mathrm{m})$; found in one sample: $533-38-2$, $15-17 \mathrm{~cm}$.

Eponides polius Phleger and Parker, 1951, p. 21, pl. 11, figs. 1-2.

Distribution. Deep species.

Site 533. Sparse and never abundant $(<5 \%)$ in some Pleistocene and upper Pliocene levels.

Eponides pusillus Parr, 1950, p. 360, pl. 14, fig. 16.

Distribution. Widespread in different seas.

Site 533. Always $<5 \%$ in some upper Pliocene and Pleistocene levels.

Francesita advena $($ Cushman $)=$ Virgulina $(?)$ advena Cushman, 1922, p. 120, pl. 25 , figs. $1-3$.

Distribution. Abyssal zone.

Site 533. In two Pleistocene samples $(<5 \%)$.

Globobulimina affinis (D'Orbigny) $=$ Bulimina affinis D'Orbigny, 1839.

Globobulimina pyrula (D'Orbigny) $=$ Bulimina pyrula D'Orbigny, 1846.

Distribution. These two species of Globobulimina are generally found in upper and middle bathyal zones. In the Gulf of Mexico, according to Pflum and Frerichs (1976), the smooth forms of Globobulimina have a large depth distribution from lower neritic to abyssal depth. But this group of species seems to be also sensitive to the oxygen content (Ingle, 1980; Mullineaux and Lohmann, 1981).

Site 533. Frequent and sometimes abundant in the Pleistocene and upper Pliocene.

Globocassidulina moluccensis Germeraad = Cassidulina moluccensis Germeraad, 1946.

Distribution. In the Gulf of Mexico, the upper depth limit of $G$. moluccensis is about $1400 \mathrm{~m}$. Burke (1981) considers this species independent from depth but corresponding to carbonate deficiency.

Site 533. It is present only in the upper sample (533-1-1, 2.5-3.5).

Globocassidulina subglobosa $($ Brady $)=$ Cassidulina subglobosa Brady, 1881,1884 , p. 430 , pl. 54 , fig. 17.

Distribution. Widespread in the bathyal zone, this species is controlled by temperature, oxygen contents, and, perhaps, salinity.

Hole 533A: Sample 533A-29-3, 40-42 cm.

Gyroidina soldanii (D'Orbigny) = Rotalia soldanii D'Orbigny, 1826.

Gyroidina neosoldanii Brotzen, 1836.

Distribution. These two species of Gyroidina are recorded from middle bathyal to upper abyssal zones.

Holes 533 and 533A. The former is present in two levels in the upper Pliocene, the latter is more frequent and occurs in the middle Pliocene, upper Pliocene, and Pleistocene.

Hoglundina elegans (D'Orbigny) $=$ Rotalia (Turbinulina) elegans D’Orbigny, 1826.

Distribution. World-wide species with large depth range from the upper to lower bathyal.

Site 533. Frequent in the upper Pliocene and Pleistocene levels.

Karreriella apicularis $($ Cushman $)=$ Gaudryina apicularis Cushman, 1911 , pp. 69-70, fig. 110.

Distribution. It is generally reported deeper than $4000 \mathrm{~m}$. In the Gulf of Mexico, this species is present from the upper bathyal to abyssal zones.

Site 533. In the upper level only (Sample 533-1-1, 2.5-3.5 cm).

Karreriella bradyi $($ Cushman $)=$ Gaudryina bradyi Cushman, 1911 p. 67, fig. 107.

Distribution. As Eggerella bradyi.

Site 533. Frequent but never abundant in uppermost Pliocene and lower Pleistocene.

Laticarinina pauperata $($ Parker and Jones $)=$ Pulvinulina repanda $\mathrm{F}$. and $\mathrm{M}$. var. menardii D'Orbigny subvar. pauperata $\mathrm{P}$. and J. 1865. Distribution. Bathyal species, occurring specially in warm intervals of cores (Lutze, 1979).

Site 533. One occurrence: Sample 533-40,CC.

Marginulina obesa $=$ Marginulina glabra Flint (non D'Orbigny), 1899 $=$ Marginulina glabra obesa Cushman, 1923, p. 128, pl. 37, fig. 1 . Site 533. Rare, in upper Pliocene and lowermost Pleistocene.

Martinotiella communis (D'Orbigny) = Clavulina communis D'Orbigny, 1846.
Distribution. Large stratigraphic range (from Miocene to Recent) and large distribution in recent seas, generally bathyal (upper bathyal).

Site 533. Frequent and somewhat abundant (up to $11 \%$ ) in lower Pleistocene samples.

Melonis formosum $($ Segnenza $)=$ Nonionina formosa Segnenza 1880.

Remarks. $M$. formosum is a moderately compressed species without limbate sutures and clear rim around the umbilicus. These characters differentiate it from $M$. barleanum.

Distribution. Described in Miocene sediments of Calabria, this species occurs also in Pliocene, Pleistocene, and Recent sediments.

Holes 533 and 533A. Frequent and sometimes abundant (up to $40 \%$ ) in all the stratigraphic sections investigated (middle Pliocene, upper Pliocene, Pleistocene, and Recent).

Melonis barleeanum (Williamson) $=$ Nonionina barleeana Williamson, 1858.

Remarks. It is questionable whether or not $M$. parkeri described from the Gulf of Biscay (Berthois and Le Calvey, 1959, p. 363, pl. 1, figs. 13-14) is synonymous. According to Rouvillois (1970, pp. 200202), $M$. parkeri has an imperforate apertural face, whereas $M$. barleeanum would have a perforate one.

The apertural face of my specimens from Holes 533 and 533A are imperforate and so are also the specimens figured by Pflum and Frerichs (1976) from the Gulf of Mexico. J. Murray (1971) states that $M$. pompilioides, in which he includes $M$. barleeanum, has an imperforate apertural face, p. 199). This taxonomic problem needs further study.

Distribution. Melonis barleeanum is generally considered a bathyal species. Nevertheless, it seems to have a larger bathymetric range than $M$. pompilioides. In the Mediterranean Sea, "M. parkeri" occurs in muddy sediments from outer shelf to lower bathyal zones. In the Atlantic, it is sometimes considered a warm species (interglacial and postglacial).

Holes 533 and 533A. Frequent (from middle Pliocene to Recent). Melonis pompilioides $($ Fichtel and $\mathrm{Moll})=$ Nautilus pompilioides Fichtel and Moll, 1798.

Distribution. In Recent sediments, this species is generally found in the lower bathyal zone, but in the past, it may have responded to climatic changes by bathymetric migrations.

Site 533. Frequent and often abundant from upper Pleistocene to Recent.

Nodosaria obliquata (Batsch) $=$ Nautilus (Orthoceras) obliquatus Batsch, 1791.

Site 533. Frequent in upper Pliocene and Pleistocene.

Nodosaria ovicula D'Orbigny, 1826 ,

Hole 533A. 10\% in Sample 533-29,CC (middle Pliocene).

Nonionella aff. $N$. miocenica Cushman var. stella Cushman and Mayer, 1930 , p. 56, pl. 7, fig. 17.

Distribution. Neritic.

Site 533. This species occurs with few specimens in three Pleistocene levels. It is probably displaced from the shelf.

Nuttalites rugosus-convexus (Parker) = Epistominella rugosa-convexa Parker, 1858, p. 273, pl. 4, figs. 21-23.

Remark. The specimen seems analogous to the Mediterranean ones found by Parker and reported also by Wright (1978).

Site 533. Sample 533-38X, 17-19 cm.

Oridorsalis umbonatus (Reuss) $=$ Rotalina umbonata Reuss, 1851.

Distribution. This species is frequent in all oceans (middle bathyal to abyssal).

Holes 533 and 533A. Frequent and sometimes abundant.

Orthomorphina fistuca (Schwager) $=$ Nodosaria fistuca Schwager, 1866.

Distribution. This species is considered extinct at the base of the Brunhes epoch (Lutze, 1979).

Site 533. Upper Pliocene and lower Pleistocene, up to Sample 533$33, \mathrm{CC}$.

Osangularia cultur (Parker and Jones) $=$ Planorbulina cultur Parker and Jones, 1865.

Distribution. Upper depth limit in middle bathyal zone.

Site 533. One occurrence: Sample 533-39-3, 33-35 cm.

Plectofrondicularia advena $($ Cushman $)=$ Fronidcularia adven $a$ Cushman, 1922 , p. 141 , pl. 20 , figs. $1-2$.

Distribution. According to Lutze, this Pliocene species disappears at the beginning of the Brunhes epoch. 
Site 533. Abundant in some upper Pliocene levels (more than $40 \%$ in Samples 533-38-3, 25-27 cm and 533-40,CC); last occurrence: Sample $533-14, \mathrm{CC}$.

Pleurostomella alternans Schwager, 1866.

Pleurostomella cf. acuminata Cushman, 1922, p. 50, pl. 19, fig. 6 . Distribution. Deep-water form.

Site 533. The two species of Pleurostomella occur sporadically in the upper Pliocene and lower Pleistocene.

Pseudonodosaria laevigata (D'Orbigny) $=$ Nodosaria $($ Glandulina $)$ laevigata D'Orbigny, 1826.

Pullenia bulloides (D'Orbigny) $=$ Nonionina bulloides D'Orbigny, 1846.

Pullenia quinqueloba (Reuss) = Nonionina quinqueloba Reuss, 1851. Distribution. The two species of Pullenia are deep forms.

Holes 533 and 533A. Frequent and often abundant, these species are present in almost all the samples; they are interpreted as interglacial and postglacial forms (see text).

Pyrgo comata Brady) = Biloculina comata Brady, 1884, p. 144, pl. 3, fig. 9.

Pyrgo lucernula Schwager) $=$ Biloculina lucernula Schwager, 1966 .

Pyrgo murrhina (Schwager) = Biloculina murrhina Schwager, 1966. Distribution. The different species of Pyrgo are deep forms (bathyal zone).

Site 533. The genus Pyrgo is frequent in the uppermost Pliocene and in the Pleistocene.

Quinqueloculina venusta Karrer, 1868.

Distribution. Bathyal and abyssal zones.

Site 533. Present (10\%) in one upper Pliocene sample (533-41-2, 42-44 cm), more common in Pleistocene samples.

Quinqueloculina viennensis Le Calvez and Le Calvez, 1958, p. 187, pl. 5, figs. $42,44,45=$ Miliolina cuveriana Brady, 1884 (non D'Orbigny), pl. 5 , fig. 12 .

Distribution. From the Pacific (Brady) and Mediterranean (Le

Calvez and $\mathrm{La}$ Calvez) from the shelf and the upper slope.

Site 533. In Samples 533-21,CC and 533-23,CC, probably reworked. Rhabdammina linearis Brady, 1879.

Distribution. Deep species.

Site 533. In the topmost sample (533-1-1, 2.5-3.5 cm).

Sigmoilopsis schlumbergeri $($ Silvestri) $=$ Sigmoilina schlumbergeri Silvestri, 1904.

Distribution. Bathyal species.

Site 533. Uppermost Pliocene and Pleistocene.

Siphotextularia catenata $($ Cushman $)=$ Textularia catenata Cushman, 1911 , p. 23 , figs. $39-40$.

Remarks. Cushman described this species from the Pacific Ocean and further reported it from the Atlantic Ocean (1918-31, Pt. 3), p. 12 , pl. 6 , fig. 3 .

According to Phleger, Parker, and Peirson (1953), the figuration of the Atlantic form represents S. rolhauseni Phleger and Parker (1951). But Corliss (1979) thinks that the two species are synonymous. The specimen found at Site 533 seems identical with Cushman's figuration of the Pacific $S$. catenata.

Distribution. S. catenata (and also S. rolhauseni) are recorded from lower bathyal to abyssal zones.

Site 533. In several Pleistocene samples; never abundant.

Sphaeroidina bulloides D'Orbigny, 1826.

Distribution. Bathyal zone.

Site 533. Frequent but never abundant.

Stainforthia complanata (Egger) = Virgulina schreibersiana Czjzek var. complanata Egger, 1893.

Distribution. According to Phleger, Parker, and Peirson 1953, this species is found on the western Atlantic shelf and slope, but Pflum and Frerichs (1976) refer Phleger, Parker and Peirson's figure to $S$. concava. They state that the true $S$. complanata (almost entirely biseriate) is restricted to bathyal and abyssal facies.

Site 533. Stainforthia complanata is present in several samples from the upper Pliocene to Pleistocene.

Stilostomella abyssorum (Brady) $=$ Nodosaria $(?)$ abyssorum Brady, 1884 , pl. 63 , figs. 8-9.

Site 533. In one sample only: 533-39-3, 33-35 cm (upper Pliocene).

Stilostomella bradyi $($ Cushman $)=$ Sagrina virgula Brady, 1884, p. 583, pl. 76 , fig. $8=$ Nodogenerina bradyi Cushman, 1927 a, p. 79 .

Site 533. In one sample only: 533-6, CC (Pleistocene).
Stilostomella lepidula $($ Schwager $)=$ Nodosaria lepidula Schwager, 1866.

Distribution. For Lutze (1979), this species disappears at the base of the Brunhes epoch.

Site 533. Last occurrence: Sample 533-25,CC. Frequent in lower upper Pliocene and Pleistocene samples.

Trifarina angulosa (Williamson) $=$ Uvigerina angulosa Williamson, 1858.

Distribution. Reported from continental shelf and upper slope.

Site 533. One specimen, probably reworked, in Sample 533-9,CC. Triloculina tricarinata D'Orbigny, 1826.

Uvigerina asperula Czjzek, 1848.

Hole 533A. One specimen in Sample 533A-27-4, 120-122 cm (middle Pliocene).

Uvigerina canariensis D’Orbigny, 1839.

Distribution. Reported from all seas, but there are few indications about its bathymetric distribution.

Site 533. In two Pleistocene samples (533-6, CC and 533-7,CC). The one little specimen referred to this species in Sample 533-39-3, $33-35 \mathrm{~cm}$ (upper Pliocene) belongs perhaps to the species $U$. urnula.

Uvigerina hollicki Thalmann, 1950 , p. $45=$ Univeringa peregrina Cushman var. bradyana Cushman, 1923 (Pt. 4) (non Fornasini, 1900), p. 168, pl. 42, fig. 12.

The form found at Site 533 is identical to the figuration of Phleger, Parker, and Peirson, 1953 (pl. 8, figs. 1-3).

Distribution. Phleger, Parker, Peirson (1953) considered U. hollicki as deep as $U$. peregrina (see the following).

Site 533. Frequent in upper Pliocene and Pleistocene; variable abundance, up to $33 \%$.

Uvigerina peregrina Cushman, 1923 (Pt. 4), p. 168, pl. 42, fig. 11.

Remark. There is a large amount of morphological variations in the Uvigerina peregrina group. In Holes 533 and 533A, some specimens have an initial portion much more pointed than the type. Few others are referable to $U$. peregrina var. dirupta Todd.

Distribution. In the western North Atlantic, the species is now located in upper and middle bathyal, but it had a greater extension during the last glaciation.

Holes 533 and 533A: Present in all the stratigraphical sections investigated; temporarily abundant in some upper Pliocene and Pleistocene samples, which have been interpreted as glacial periods.

Uvigerina senticosa Cushman 1927b, p. 159, pl. 3, fig. 14.

Distribution. Deep species. The "deepest uvigerinid index" (Pflum and Frerichs, 1976).

Site 533. In upper Pleistocene only (15-25\%).

Uvigerina urnula D'Orbigny, 1846.

Remarks. Little form with few costae at the base of the chambers. Brady $(1884$, p. 574$)$ thought that this character was of little importance and put $U$. urnula in synonymy with $U$. canariense. In fact, some specimens have very attenuate costae and are difficult to attribute to one species or the other-this is the case for the specimens found in Sample 533-39-3, 33-35 cm.

Distribution. Miocene and Pliocene.

Holes 533 and 533A. In middle and upper Pliocene.

Valvulineria laevigata Phleger and Parker, 1951, p. 25, pl. 13, figs. 11-12.

Distribution. Bathyal species.

Site 533. Rare (in three Pleistocene samples).

\section{REFERENCES}

Bermudez, P. J., 1939. Resultados de la primera expediciòn en las Antillas del Ketch Atlantis bajo los auspicios de las Universitades de Harvard y de La Habana. Nuevo Genero y Especies Nuevas de Foraminiferos, 13(4):247-251.

Berthois, L., and Le Calvez, Y., 1959. Deuxième contribution à l'etude de la sédimentation dans le golfe de Gascogne. Rev. Trav. Inst. Peches Marit., 23(3):325-375.

Brady, H. B., 1868. On Ellipsoidina, a new genus of Foraminifera. By Giuseppe Seguenza, Professor of Natural History in the Royal Lyceum, Messina. Ann. and Mag. Nat. Hist Ser. 4, 1:333-343.

, 1884. Report on the Foraminifera dredged by H.M.S. Challenger during the years 1873-1876. Repts. Sci. Voy. H.M.S. Challenger, Zoology, Vol. 9. 
Burke, S. C., 1981. Recent benthic foraminifers from the Ontong-Java Plateau. J. Foraminiferal Res., 11(1):1-19.

Corliss, H., 1979. Taxonomy of recent deep sea benthic foraminifera from the South East Indian Ocean. Micropaleontology, 25(1):1-19.

Cushman, J. A., 1910-1916. A monograph of the Foraminifera of the North Pacific Ocean. U.S. Nat. Mus. Bull., 71, Pts. 1-6.

1918-1931. The Foraminifera of the Atlantic Ocean. U.S. Nat. Mus. Bull., 104, Pts. 1-8.

1927a. Some new genera of the Foraminifera. Cushman Lab. Foraminiferal Res. Contrib., 2(4):77-81.

1927b. Recent Foraminifera from the West Coast of America. Bull. Scripṕs Inst. Oceanogr., Tech. Ser., 1:119-188.

Ingle, J. E., 1980. Cenozoic paleobathymetry and depositional history of selected sequences within the southern California continental borderland. Cushman Found. Foraminiferal Res. Spec. Publ., 19: 163-195.

Le Calvez, J., and Le Calvez, Y., 1958. Répartition des Foraminifères dans la baie de Villefranche. I. Miliolidae. Ann. Inst. Oceanogr. Paris, pp. 160-234.

Lutze, G. F., 1977. Neogene benthonic foraminifera from Site 369, Leg 41. In Lancelot, Y., Seibold, E., et al., Init. Repts. DSDP, 41: Washington (U.S. Govt. Printing Office), 659-666. 1979. Benthic foraminifera at Site 397: faunal fluctuations and ranges in the Quaternary. In Von Rad, U., Ryan, W. B. F., et al., Init. Repts. DSDP, 47, Pt. 1: Washington (U.S. Govt. Printing Office), 419-432.

Mullineaux, L. S., and Lohmann, G. P., 1981. Late Quaternary stagnation and recirculation of the eastern Mediterranean. Changes in the deep water recorded by benthic fossil foraminifera. J. Foraminiferal Res, , 11(1):20-30.

Murray, J., 1971. An Atlas of British Recent Foraminiferids: London (Heinemann Educ. Books).

Parr, W. J., 1950. Foraminifera. B.A.N.Z. Antarctic Res. Exped. 1929-1931 Repts. Ser. B, 5(6):232-392.

Pflum, C. E., and Frerichs, W. E,. 1976. Gulf of Mexico deep water foraminifera. Cushman Lab. Foraminiferal Res. Spec. Publ., 14:1-125.

Phleger, F. B., and Parker, F. L., 1951. Ecology of Foraminifera, northwest gulf of Mexico, Pt. II: Foraminifera species. Geol. Soc. Am. Mem., 46:1-64.

Phleger, F. B., Parker, F. L., and Peirson, J., 1953. Sediment cores from the North Atlantic Ocean. Rep. Swed. Deep-Sea Exped., 8: 1-122.

Rouvillois, A., 1970. Biocoenoses et taphocoenoses de Foraminiferes sur le plateau continental atlantique au large de l'île d'Yeu. Rev. Micropaleontol., 13(3):188-204.

Schnitker, D., 1980. Quaternary benthic foraminifers and bottom water masses. Ann. Rev. Planet. Sci., 8:343-370.

Thalmann, H. E., 1950. New names and homonyms in Foraminifera. Cushman Found. Foraminiferal Res. Contrib., 1:41-45.

Wright, R. W., 1978. Neogene benthic foraminifers from DSDP Leg $42 \mathrm{~A}$, Mediterranean Sea. In Hsü, K., Montadert, L., et al., Init. Repts. DSDP, 42(Pt. 1): Washington (U.S. Govt. Printing Office), 709-726. 

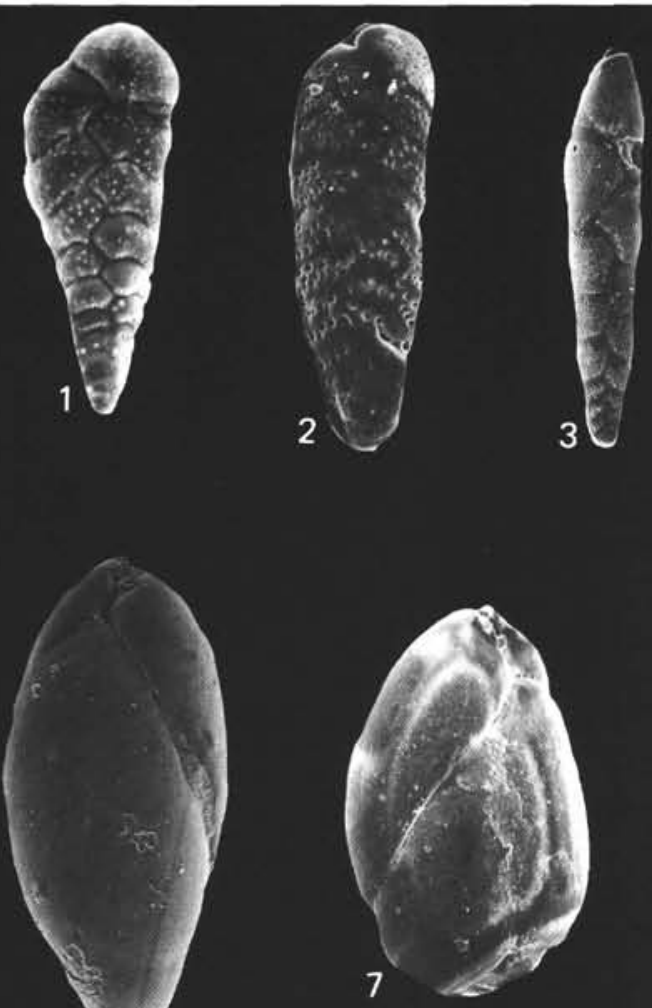

6

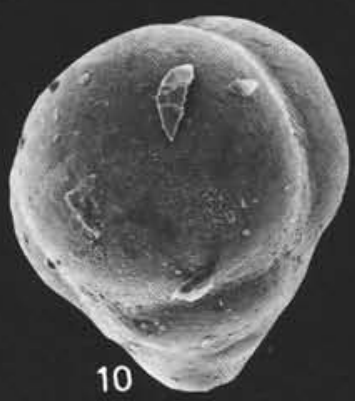

14

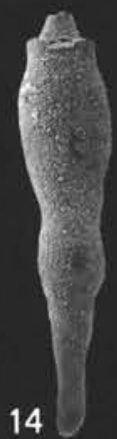

\section{1}
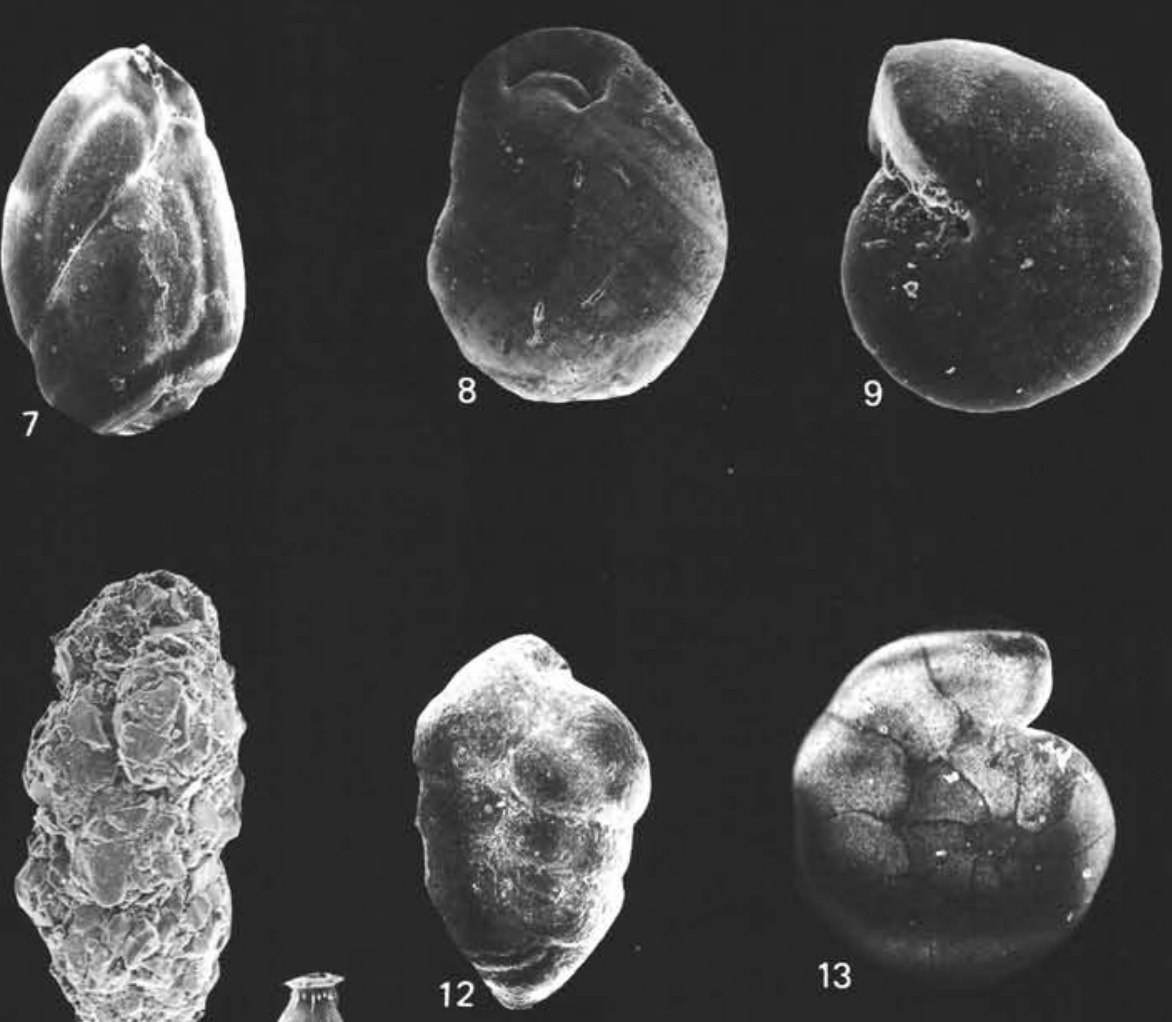

9
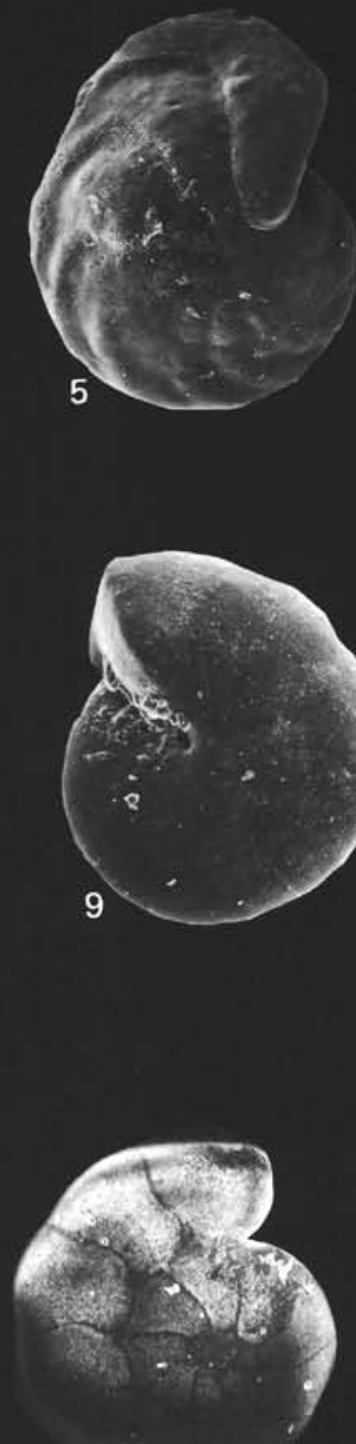

13

12

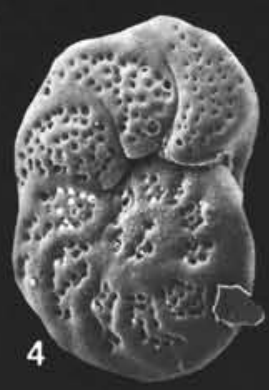

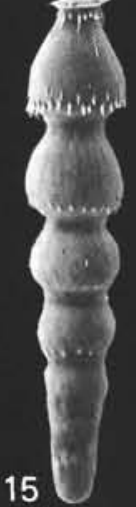

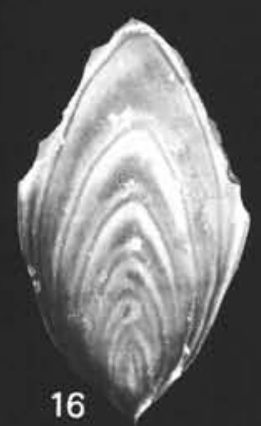

Plate 1. 1. Bolivina sp., $\times 20$. Sample 533-23,CC. 2. Bolivina ex gr. spathulata (Williamson), $\times 185$. Sample 533-23,CC. 3. Bolivina seminuda Cushman, $\times 185$. Sample 533,23,CC. 4-5. Cibicides wuellestorfi (Schwager), $\times 93$. Sample 533-25,CC. 6. Globobulimina affinis (d'Orbigny), $\times 74$. Sample 533-23,CC. 7. Globobulimina pyrula (d'Orbigny), $\times 65$. Sample 533-25,CC. 8. Globocassidulina moluccensis Germeraad, $\times 65$ (Sample 533-1-1, 2.5-3.5 cm. 9, 13. Gyroidina neosoldanii Brotzen, $\times 65$. Sample 533-23,CC. 10. Karreriella bradyi (Cushman), $\times 130$. Sample 533-23,CC. 11. Karreriella apicularis (Cushman), $\times 167$ (Sample 533-1-1, 2.5-3.5 cm. 12. Eggerella bradyi (Cushman), $\times 215$. Sample 533-21,CC. 14. Orthomorphina fistuca (Schwager), $\times 37$. Sample 533-8-2, 15-17 cm. 15. Stilostomella ex gr. lepidula (Schwager) $\times 185$. Sample 533-35-2, 25-27 cm. 16. Plectofrondicularia advena (Cushman), $\times 65$. Sample 533-40,CC. 

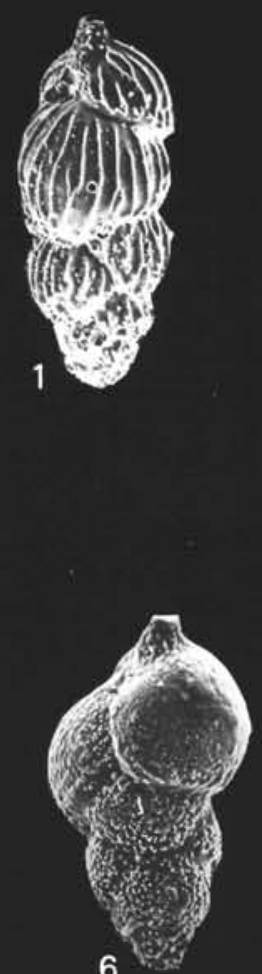

6

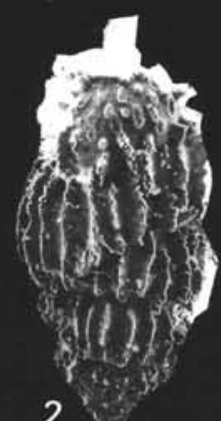

2 ris
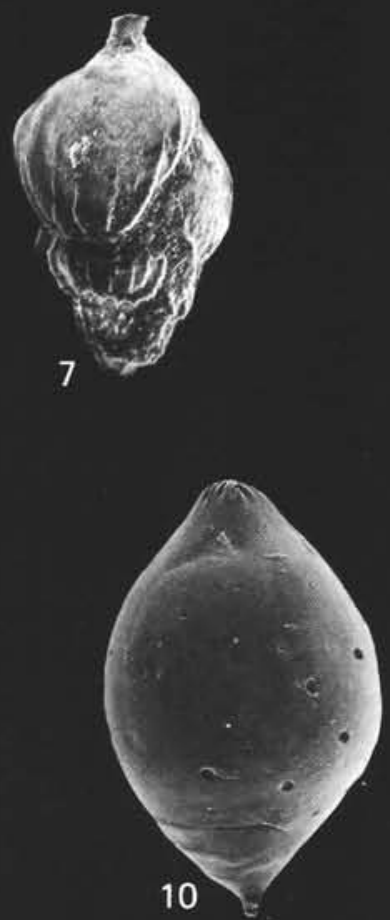
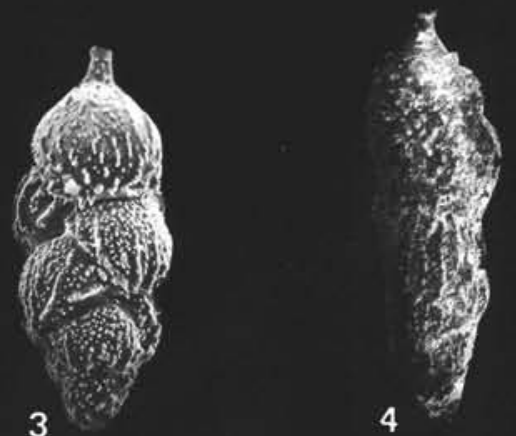

4
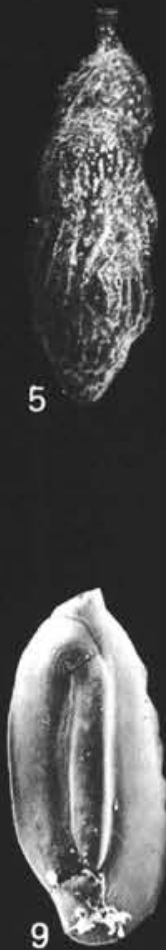

8
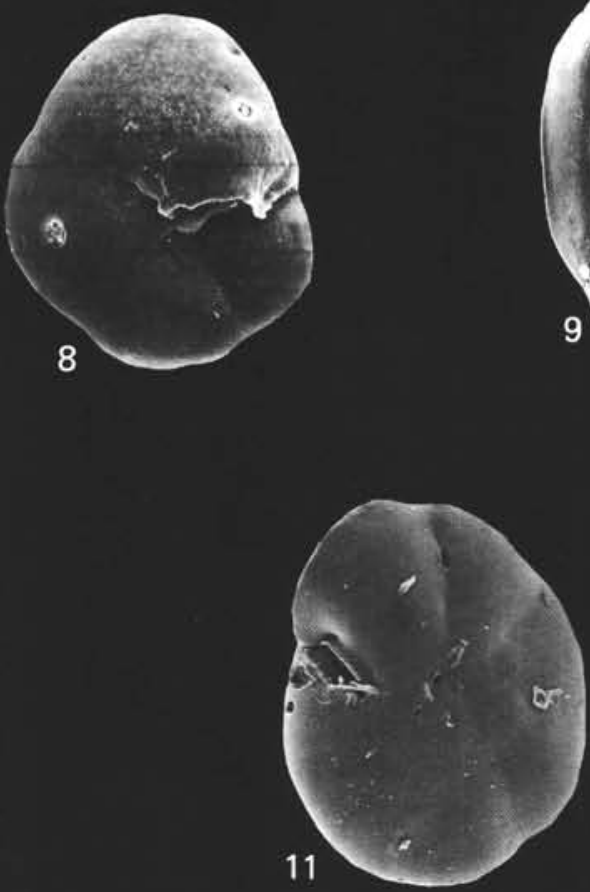

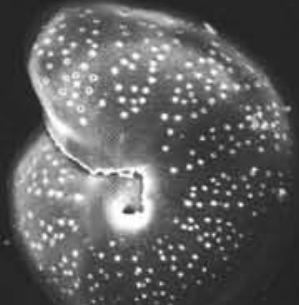

12
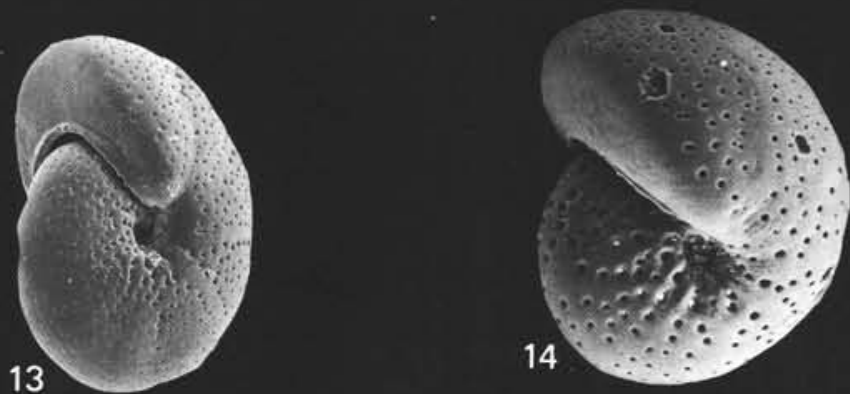

Plate 2. 1-2. Uvigerina ex gr. peregrina Cushman, $\times 65$. Sample $533-39-3,33-35 \mathrm{~cm}$. (1) U. peregrina peregrina Cushman, (2) U. peregrina dirupta Todd. 3. Uvigerina cf. peregrina Cushman, $\times 65$. Sample $533-39-3,33-35 \mathrm{~cm}$. (The form is intermediate between $U$. peregrina and $U$. hollicki). 4-5. Uvigerina hollicki Thalmann, $\times 65$. Sample 533-33,CC. 6. Uvigerina senticosa Cushman, $\times 102$. Sample 533-38-1, 75-77 cm). 7. Uvigerina cf. urnula d'Orbigny, $\times 150$. Sample $533-39-36,33-35 \mathrm{~cm}$. 8. Valvulineria laevigata Phleger and Parker, $\times 185$. Sample $533-14, \mathrm{CC} .9$. Quinqueloculina venusta Karrer, $\times 93$. Sample 533-25,CC. 10. Pseudonodosaria laevigata (d'Orbigny), $\times 140$. Sample 533-41-2, 42-44 $\mathrm{cm}$. 11. Oridorsalis umbonatus (Reuss), $\times 130$. Sample 533-26,CC. 12-13. Melonis barleeanum Williamson), $\times 112$. Sample 533-31,CC. 14. Melonis pompiliodes (Fichtel and Moll), $\times 112$. Sample 533-21.CC. 